\title{
VARTOTOJŲ PASITENKINIMO KAUNO MIESTO PICERIJOMIS NUSTATYMAS
}

\author{
Viktorija Grigaliūnaité丶 ${ }^{1}$, Lina Pileliené² \\ Vytauto Didžiojo universitetas (Lietuva)
}

\begin{abstract}
ANOTACIJA
Maitinimo įstaigų populiarumo Lietuvoje didèjimas pagrindžia vartotojų pasitenkinimo šiomis įstaigomis tyrimo aktualumą. Vertinant itališkos virtuvès atitikimą tradiciniam lietuvio skoniui, tyrimą nuspręsta atlikti picerijų sektoriuje. Tiriant siekta ịvertinti vartotojų pasitenkinimą Kauno miesto picerijomis. Tyrimo duomenys leidžia daryti išvadą, kad siekiant didesnio vartotojų pasitenkinimo picerijomis, svarbiausia suderinti vartotojų lūkesčius ir produktų bei aptarnavimo kokybę. Apibendrinus atlikto tyrimo rezultatus, sudarytas vartotojų pasitenkinimo Kauno miesto picerijomis modelis, kuris gali būti taikomas apskaičiuojant vartotojų pasitenkinimą visomis picerijomis arba konkrečia Kauno miesto picerija, taip pat adaptuotas kitų miestų picerijų ar kitų maitinimo įstaigų vartotojų pasitenkinimui matuoti.

PAGRINDINIAI ŽODŽIAI: ECSI, Kaunas, maitinimo paslaugos, vartotoju pasitenkinimas.
\end{abstract}

JEL KLASIFIKACIJA: L660, M310.

\section{Ivadas}

Tyrimo aktualumas. Maistas - pirmo būtinumo prekè, be kurios pasaulyje neapsieina nè vienas žmogus. Greitèjant žmonių gyvenimo tempui ir didèjant jų užimtumui atsiranda daug ịvairaus tipo greito maisto restoranu. Spartẻjanti techninė pažanga, kai tolimos šalys pasiekiamos per kelias valandas, ir globalizacija, kai verslas neapsiriboja vienos šalies teritorija, o siekia užimti ir kitų šalių rinkas, lėmė galimybę žmonèms paragauti svetimų šalių virtuvès patiekalų ir pagal savo skonį išsirinkti mėgstamiausią maistą. Todèl atsirado daug ịvairių ne nacionalinės virtuvės restoranų, kurie teikia kitų šalių tradicinius patiekalus.

Maitinimo isstaigu populiarumas neaplenkè ir Lietuvos bei antro pagal dydį Lietuvos miesto Kauno. Statistikos departamento duomenimis (2012), Kaune 2011 metais gyveno daugiau kaip 330 tūkstančiu gyventojų, o i̇monių, užsiimančių maitinimo ir gèrimų teikimo veikla, buvo 470 (bendras vietų skaičius - 26 200). Tai reiškia, kad maitinimo isstaigų vietų yra tik 13 kartų mažiau nei Kaune iš viso gyvena žmonių ir tai rodo maitinimo įstaigų populiarumą visuomenèje. Dažniausiai maitinimo ịstaigoms priskiriami restoranai, picerijos, kavinès, barai, greitojo maisto restoranai, sveikojo maisto restoranai, vyninès, alaus restoranai, pakelès kavinès, valgyklos ir ịvairūs šių ịstaigų deriniai. Ivertinant itališkos virtuvės populiarumą Lietuvoje, tyrimą nuspręsta atlikti picerijų sektoriuje.

Tyrimo problema: ar vartotojai patenkinti Kauno miesto picerijų paslaugomis, kokie veiksniai tą pasitenkinimą lemia.

1 Viktorija Grigaliūnaitè - Vytauto Didžiojo universiteto Ekonomikos ir vadybos fakultetas, bakalaure. Mokslinès kryptys: vartotojų pasitenkinimas, matematikos metodai rinkotyroje.

El.paštas: v.grigaliunaite@fc.vdu.lt.

Tel.: +370 37327856 .

2 Lina Pilelienè - Vytauto Didžiojo universiteto Ekonomikos ir vadybos fakulteto Ekonomikos katedros docentè, daktarè (socialiniai mokslai). Mokslinès kryptys: vartotojų elgsena, vietovès rinkotyroje.

El. paštas: 1.pileliene@evf.vdu.1t.

Tel.: +37037327856. 
Straipsnio objektas - vartotojų pasitenkinimas Kauno miesto picerijomis.

Straipsnio tikslas - ivertinti vartotojų pasitenkinimą Kauno miesto picerijomis.

Siekiant straipsnio tikslo keliami šie uždaviniai:

- aptarti vartotojų pasitenkinimo sampratą ir pateikti modelius;

- atlikti vartotojų pasitenkinimo Kauno miesto picerijomis tyrima;

- sudaryti vartotojų pasitenkinimo Kauno miesto picerijomis modeli.

Tyrimo metodai. Siekiant atskleisti vartotojų pasitenkinimo sampratą ir sudaryti modelius, kurie bus taikomi, atliekant vartotojų pasitenkinimo Kauno miesto picerijomis tyrimą, atliekama teorinè mokslinès literatūros analizè ir sintezè. Vartotojų požiūriai ir Kauno miesto picerijų vertinimas nustatomi atliekant anketinę apklausą. Statistinei apklausos duomenų analizei atlikti taikytas struktūrinių lygčių modeliavimas (SEM) mažiausių dalinių kvadratų (PLS) metodu, regresinè analizè, koreliaciné analizé, loginė analizè.

\section{Vartotojų pasitenkinimo samprata}

Vienas pirmujų rinkotyros specialistu, tyręs vartotojų pasitenkinimą, buvo R. N. Cardozo (1965). Pastaraisiais dešimtmečiais vartotoju pasitenkinimo sąvoka susilaukia vis daugiau organizacijų dèmesio. Pagrindinis veiksnys, skatinantis organizacijas skirti vis daugiau dėmesio vartotojų pasitenkinimui, - didesnis vartotojų pasitenkinimas gali lemti palankesnę konkurencinę padètị rinkoje, todèl didèja užimama rinkos dalis ir pelnas (Fornell, 1992). Vartotojų pasitenkinimas laikomas reikšmingu pakartotinių pirkimų, teigiamų atsiliepimų ir vartotojų lojalumo veiksniu. Patenkinti klientai grižta, daugiau perka ir apie savo patirti pasakoja kitiems žmonėms (Fornell ir kt., 1996). Todèl vienas organizacijos tikslų tampa vartotojų pasitenkinimo siekis.

R. L. Day (1984) vartotojo pasitenkinimą / nepasitenkinimą apibrèžè kaip vartotojo reakciją i tam tikro produkto vartojimo patirtyje jaučiamo skirtumo tarp vartotojo lūkesčių ir issigyto produkto neatitikimo lūkesčiams ịvertinimą. Vartotojas yra patenkintas, kai prekẻ tenkina jo lūkesčius, ir priešingai, jei prekè vartotojo lūkesčių netenkina, jis yra nepatenkintas. Gali būti, kad prekẻ vartotojo lūkesčius viršija, tada jis būna labai patenkintas (sužavètas). Pastaraisiais metais vartotoju pasitenkinimo sąvokos esmé nepakito, daugelis autorių pasitenkinima apibrèžia kaip skirtumo tarp vartotojo lūkesčių ir i̇sigytos prekės ar paslaugos suvokimo rezultatą (Appiah-Gyimah ir kt., 2011). Todèl, glaustai nusakant vartotojo pasitenkinimą produktu ar paslauga, galima teigti, kad jis bus patenkintas, kai produktas ar paslauga atitiks jo lūkesčius.

Matuojant vartotojų pasitenkinimą nustatoma, kiek organizacijos produktai ar paslaugos atitinka jų lūkesčius (Krishan ir kt., 2011). Kai kurie autoriai (Boulding ir kt., 1993; Johnson ir kt., 1995; Fornell ir kt., 1996; Chan ir kt., 2003) skiria transakcini specifinį ir sukauptą pasitenkinimą. Transakcinis specifinis pasitenkinimas - pasitenkinimas konkrečiu pirkiniu, atsiradęs ji vartojant, o sukauptas pasitenkinimas atskleidžia bendrą pasitenkinimą, kuris pagrįstas produkto pirkimo ir vartojimo patirtimi per tam tikrą laiką. Išmatuotas transakcinis specifinis pasitenkinimas gali suteikti diagnostinès informacijos apie tam tikrą produktą ar paslaugą (Fornell ir kt., 1996). Sukauptojo pasitenkinimo ịvertinimas yra gana nauja ir naudingesnè už transakcinio specifinio pasitenkinimo matavimą idejja, prognozuojant vartotojų elgseną bei įmonès ekonominès veiklos rezultatus (Chan ir kt., 2003). Matuojant bendrą vartotojų pasitenkinimą i̇monès gaminiais / paslaugomis, imoniu grupe ar visa pramonès šaka, tikslingiau matuoti sukauptą pasitenkinimą, nes taip galima ịvertinti ir prognozuoti ilgalaikius procesus. Todèl atliekant tyrimą vartotojų pasitenkinimas siejamas su sukauptu pasitenkinimu.

Mokslinèje literatūroje pateikiama nemažai vartotojų pasitenkinimo modelių, kurie leidžia matuoti vartotojų pasitenkinimą. Žinomiausi: Švedijos vartotojų pasitenkinimo barometras (SCSB), Amerikos vartotoju pasitenkinimo indeksas (ACSI), Vokietijos barometras, Šveicarijos vartotoju pasitenkinimo indeksas (SWICS), Norvegijos vartotojų pasitenkinimo barometras (NCSB), Europos vartotojų pasitenkinimo indeksas (ECSI), Korejos vartotojų pasitenkinimo indeksas (KCSI), Malaizijos vartotojų pasitenkinimo indeksas (MCSI), Honkongo vartotojų pasitenkinimo indeksas (HKCSI). Brazilija, Argentina, Meksika, Kanada, Australija, Taivanas ir kai kurie kiti regionai taip pat turi savo VPI sistemas (Yang ir kt., 2005). 
Straipsnyje pateikiami vartotojų pasitenkinimo Kauno miesto picerijomis tyrimo rezultatai. Gautus tyrimo rezultatus naudinga palyginti su kitų maitinimo ịstaigų vartotojų pasitenkinimo tyrimo rezultatais, kitų pramonės šakų Kaune pasitenkinimo tyrimų rezultatais, taip nustatant picerijų Kaune silpnąsias ir stipriąsias veiklos vietas, kurios susijusios su vartotojų pasitenkinimo, jo priežasčių bei pasekmių organizacijai aspektais.

\section{Vartotoju pasitenkinimo modelio parinkimas}

Atliekant tyrimą, nuspręsta taikyti koreguotą Europos vartotojų pasitenkinimo indekso modeli (ECSI), kuri sudaro pagrindinis modelis su tradiciniais neatskleistais kintamaisiais - suvokiama kokybe (itraukti abu kokybės aspektai: produkto ir paslaugos / aptarnavimo kokybė), lūkesčiais, suvokiama verte, pasitenkinimo indeksu, vartotojų lojalumu ir ryšiais tarp jų bei du papildomi neatskleisti kintamieji, kuriuos prideda nacionaliniai komitetai - įvaizdis ir vartotojų skundai bei ryšiai tarp jų (Bayol ir kt., 2000). Pagal ši modeli skaičiuojant vartotojų pasitenkinimą įvertinama daugiausiai vartotojų pasitenkinimą lemiančių veiksnių ir visos tiesioginės vartotoju pasitenkinimo pasekmės organizacijai. Modelis pritaikytas kiekvieno vartotojo pasitenkinimą lemiančiam veiksniui ir jo pasekmių organizacijai itakos laipsniui matuoti bei galimiems ryšiams tarp jų paaiškinti. Modelis padès nustatyti vartotojų pasitenkinimą Kauno miesto picerijomis, tam tikrą pasitenkinimą lemiančius veiksnius ir kiek kuris veiksnys lemia atitinkamą pasitenkinimą. Tai leidžia organizacijai efektyviai paskirstyti ribotus išteklius didinant vartotoju pasitenkinimą.

Pasirinktame modelyje pateikti 7 neatskleisti kintamieji. Pateikiamas vienas egzogeninis veiksnys ivaizdis, i kurį nenukreiptos jokios rodyklès, ji veikia išoriniai, vartotoju pasitenkinimo modelyje neivardyti veiksniai. Šeši veiksniai yra endogeniniai. I juos nukreiptos rodyklès iš tų modelyje įvardytų veiksnių, kurie, manoma, juos lemia.

Daromos prielaidos, kad įvaizdis lemia vartotojų lūkesčius, vartotojų pasitenkinimą ir lojalumą. Vartotojų lūkesčiai lemia suvokiamus kokybę, vertę ir vartotojų pasitenkinimą. Suvokiama kokybẻ lemia suvokiamą vertę ir vartotojų pasitenkinimą. Suvokiama vertė lemia vartotojų pasitenkinimą. Vartotojų pasitenkinimas veikia vartotojų lojalumą ir skundus. Skundai daro ịtaką lojalumui. Visi išvardyti ryšiai susiję tiesiogine teigiama įtaka, išskyrus skundus, kurie veikiami pasitenkinimo ir veikia lojalumą darydami tiesioginę atvirkštinę ịtaką. Modelyje šie ryšiai sudaryti remiantis įvairiomis mokslinėmis teorijomis ir tyrimais, tačiau kiekvienu vartotojų pasitenkinimo tyrimo atveju ryšių stiprumas ir net patys ryšiai yra skirtingi ir priklauso nuo šalies, kurioje tyrimas atliekamas, pramonès šakos, paslaugos ar produkto, vartotojų požiūrių ir daugelio kitų veiksnių, todèl šie ryšiai yra tik bendra nuoroda, rodanti galimus ryšius.

\section{Tyrimo metodika}

\subsection{Duomenu rinkimo metodas}

Tyrimui atlikti pasirinktas kiekybinis pirminių duomenų rinkimo metodas, tai grindžiant tuo, kad vartotojų pasitenkinimas gali būti išreiškiamas skaičiais ir matuojamas. Pirminiai tyrimo duomenys rinkti pasitelkus anketas, kur pateikti iš anksto parengti klausimai. Anketa yra standartizuoto tipo: klausimai visiems respondentams yra vienodi ir nesikeičia jų pateikimo tvarka. Duomenis rinkti taikant anketas pasirinkta todèl, kad parengti standartiniai anketos klausimai, kurie užduodami respondentams skaičiuojant vartotojų pasitenkinimą taikant ECSI modelị. Atsižvelgiant i šali, vartotojų požiūrị, produktą ar paslauga, 15-25 klausimai, skirti vartotojų pasitenkinimui apskaičiuoti, gali būti modifikuojami, tačiau jų esmè lieka ta pati (Eklof ir kt., 2008).

Klausimai-teiginiai, kurie pateikiami respondentams, siekiant apskaičiuoti vartotojų pasitenkinimą, vadinami akivaizdžiais kintamaisiais. Šie susiję kintamieji sujungiami i 7 neatskleistus kintamuosius. Tyrime 
naudojama anketa sudaryta iš 3 dalių. Pirmoji dalis (1-as ir 3-ias klausimai) - tai klausimai, atliekantys klausimo filtro funkcija, siekiant nustatyti, ar respondentas yra tinkamas. Antroji dalis (2-as klausimas) - tai klausimai, padedantys apskaičiuoti vartotojų pasitenkinimą Kauno miesto picerijomis. Trečioji dalis (4-as, 5-as, 6-as klausimai) - tai klasifikavimo klausimai, pateikiami siekiant gauti informaciją, kuri leistu grupuoti respondentus ir juos apibūdinti.

Tyrime naudojami akivaizdūs ir neatskleisti kintamieji, skirti vartotojų pasitenkinimui Kauno miesto picerijomis nustatyti, pateikiami 1 lenteleje. Tyrimo gylis, t. y. klausimų respondentams skaičius, yra 23. Anketa atitinka ECSI standartus. Tyrime laikomasi nuostatos, kad organizacijos įvaizdi atskleidžia bendra nuomone apie organizacija, patikimumas, profesionalumas, naujumas (Turkyilmaz, Ozkan, 2007) ir vartotojo nuomoné apie tai, kiek organizacija orientuota i vartotojus (O’Loughlin, Coenders, 2004).

\section{Lentele 1. Neatskleisti ir akivaizdūs kintamieji}

\begin{tabular}{|c|c|c|}
\hline Neatskleisti kintamieji & Akivaizdūs kintamieji & Trumpinys \\
\hline \multirow{5}{*}{ Ivaizdis $(\xi 1)$} & Kauno picerijų ivaizdis visuomenèje yra teigiamas & IMAG1 \\
\hline & Picerijos yra naujoviškos & IMAG2 \\
\hline & Picerijos orientuotos i vartotojus & IMAG3 \\
\hline & Picerijose geras aptarnavimas & IMAG4 \\
\hline & Picerijomis visiškai pasitikiu & IMAG5 \\
\hline \multirow{3}{*}{ Vartotojų lūkesčiai ( $(\xi 2)$} & Pasirinkęs Kauno miesto picerijas, tikèjausi aukštos kokybės & CUEX1 \\
\hline & Tikejjausi labai geros produkto kokybės & CUEX2 \\
\hline & Tikëjausi labai gero aptarnavimo & CUEX3 \\
\hline \multirow{6}{*}{ Suvokiama kokybè ( $(3)$} & Bendrai teikiamus Kauno miesto piceriju produktus vertinu labai gerai & PERQ1 \\
\hline & Bendrai Kauno miesto picerijų aptarnavimą vertinu labai gerai & PERQ2 \\
\hline & Produktų kokybė visiškai tenkina mano keliamus reikalavimus & PERQ3 \\
\hline & Aptarnavimo kokybė visiškai tenkina mano keliamus reikalavimus & PERQ4 \\
\hline & $\begin{array}{l}\begin{array}{l}\text { Produktu kokybè, lyginant su kitomis maitinimo istaigomis, yra labai } \\
\text { gera }\end{array} \\
\end{array}$ & PERQ5 \\
\hline & $\begin{array}{l}\text { Aptarnavimo kokybè, lyginant su kitomis maitinimo istaigomis, yra labai } \\
\text { gera }\end{array}$ & PERQ6 \\
\hline \multirow{2}{*}{ Suvokiama verte $(\xi 4)$} & Produktų kokybė visiškai atitinka už produktus sumokètą kainą & PERV1 \\
\hline & Kaina visiškai atitinka gautą kokybę & PERV2 \\
\hline \multirow{3}{*}{ Vartotojų pasitenkinimas $(\xi 5)$} & Bendras pasitenkinimas produktu ir aptarnavimu yra labai geras & CUSA1 \\
\hline & Picerijos visiškai atitiko mano lūkesčius & CUSA2 \\
\hline & Kauno miesto picerijos yra netoli nuo idealo & CUSA3 \\
\hline \multirow{2}{*}{ Vartotojų skundai ( $\xi 6)$} & $\begin{array}{l}\text { Jei netenkina picerijos teikiamo produkto ar aptarnavimo kokybè, } \\
\text { skundžiatès draugams ir giminaičiams }\end{array}$ & CUSCO1 \\
\hline & $\begin{array}{l}\text { Jei netenkina picerijos teikiamo produkto ar aptarnavimo kokybè, } \\
\text { skundžiatès picerijos vadovybei }\end{array}$ & CUSCO2 \\
\hline \multirow{2}{*}{ Vartotojų lojalumas ( $(7)$} & Planuoju lankytis Kauno miesto picerijose ateityje & CUSL1 \\
\hline & Kauno miesto picerijas rekomenduočiau draugams ir pažistamiems & CUSL2 \\
\hline
\end{tabular}

1 lentelëje pateikti teiginiai apie picerijų i̇vaizdi visuomenèje (bendra nuomonè), naujumą, orientaciją i vartotojus, būdingą aptarnavimą (profesionalumas) ir pasitikèjimą picerijomis (patikimumas) yra susiję su ịvaizdžiu, asociacijomis, kurių kyla vartotojui pagalvojus apie picerijas, todèl šie akivaizdūs kintamieji matuoja ịvaizdžio neatskleistą kintamaji. Vartotojų lūkesčius atskleidžia tai, kokios kokybės vartotojas tikejjosi, o suvokiama kokybė apibūdinama bendru kokybės įvertinimu, atitikimu vartotojo reikalavimams (Kristensen ir kt., 1999). Vartotojų lūkesčių neatskleistą kintamaji matuoja akivaizdūs kintamieji, susiję su tuo, kokios bendros produkto ir aptarnavimo kokybės jie tikejjosi. Tai yra pagrindiniai aspektai, kuriuos picerija gali pasiūlyti, todèl būtent su jais siejami vartotojų lūkesčiai. Suvokiama kokybẻ susideda iš suvokiamos produkto ir aptarnavimo kokybès, todèl 6 teiginiai, siejami su suvokiama kokybe, sudaryti iš 3 teiginiu apie produkto ir 3 tokių pačių teiginių apie aptarnavimo kokybę. Šių teiginių dẻka nustatomas bendras vartojimo 
patirties iqvertinimas, atitikimas vartotojo reikalavimams ir palyginimas su konkurentais. Suvokiamos vertès kintamasis matuojamas akivaizdžiais kintamaisiais, kurie susiję su vartotojo suvokiamu kokybės lygiu, lyginant su kaina, bei kainą lyginant su kokybe (O'Loughlin ir kt., 2004). Vartotojų pasitenkinimą matuoja trys kintamieji: bendras pasitenkinimas produktu ir aptarnavimu, picerijų atitikimas vartotojo lūkesčiams bei palyginimas su idealu (Eklof ir kt., 2008). Vartotojų skundų kintamasis padeda nustatyti, ar jie yra linkę skųstis, jei taip, tai kam skundžiasi: atitinkamiems vadovaujantiems picerijos darbuotojams ar savo giminèms, draugams, nepranešdami picerijos atstovams, kad yra nepatenkinti produktu arba aptarnavimu ir taip netiesiogiai lemdami atitinkamus padarinius organizacijai (skųsdamasis draugams ar artimiesiems vartotojas gali pakeisti jų nuomonę dẻl organizacijos). Lojalumą rodo teiginiai, susiję su ketinimu lankytis tose pačiose picerijose ir jas rekomenduoti draugams ar artimiesiems (Ciavolino, Dahlgaard, 2007). Taigi visi akivaizdūs kintamieji priskirti tam tikram neatskleistam kintamajam. Kiekvienas kintamasis yra matuojamas, apskaičiuojamas kintamojo reikšmès lygis, ỉvertinami ryšiai tarp kintamujų. Taip užtikrinami patikimi ir tinkami rezultatai (Eklof ir kt., 2008).

Visus pateiktus teiginius respondentai vertino pagal 10 balų skalę, kur 1 reiškia visiškai neigiamą nuomonę dèl pateikto teiginio, 10 - visiškai teigiamą. Jei respondentas dèl pateikto teiginio nuomonès neturi, jam suteikiama nulinio atsakymo galimybè.

\subsection{Tiriamujų kontingentas}

Tyrimo plotis, t. y. apklaustų respondentų skaičius, yra 250 - rekomenduojamas imties dydis, skaičiuojant vartotojų pasitenkinimą pagal ECSI modeli. Teigiama, kad toks respondentų skaičius yra pakankamas, kad tyrimo rezultatai būtu patikimi.

Kadangi atliekamas skersinio pjūvio aprašomasis tyrimas neturint generalinės aibės sąrašo, imties tūrio parinkimo būdas yra netikimybinis atsitiktinis. Tyrimas atliekamas apie Kauno miesto picerijas, todèl respondentai asmeniškai apklausti Kauno mieste. Tyrimui tinkami respondentai yra tie, kurie lankosi arba lankydavosi Kauno miesto picerijose. Respondentai atrenkami ne pagal demografinius ar kitus kriterijus. Taip apklausus daugiau skirtingų pagal lyti, amžių ir gaunamas pajamas žmonių, apskaičiuotas vartotojų pasitenkinimo indeksas rodo bendrą visų Kauno miesto picerijų lankytojų pasitenkinimą.

Apklausa vykdyta 2012 metu kovo 7-21 dienomis. Tyrime dalyvavo 128 moterys (51,2\%) ir 122 vyrai (48,8 \%). Pagal amžių respondentai taip pasiskirstė: nuo jaunesnių nei 18 metų iki vyresnių nei 55 metų amžiaus. Vyraujantis respondentų amžius - 18-25 metai (47,6 \% apklaustujų). Pagal mėnesines pajamas, kurios tenka vienam šeimos nariui, respondentai pasiskirstė nuo gaunančiujų mažiau nei minimalią mènesinę algą iki gaunančiujų daugiau nei vidutines mėnesines pajamas (Lietuvos statistikos departamento [2012] duomenimis, 2011 m. 4 ketvirti vidutinis mėnesinis bruto darbo užmokestis Lietuvoje buvo 2175 Lt, minimalioji mėnesinė alga Lietuvoje - $800 \mathrm{Lt}$ ), tačiau daugiausiai apklausoje dalyvavusių respondentų teigè, kad pajamos, tenkančios vienam jų šeimos nariui, yra tarp minimalaus ir vidutinio mėnesinio atlyginimo.

\subsection{Tyrimo rezultatų apdorojimo metodas}

Vartotojų pasitenkinimo modeli sudaro vartotojų pasitenkinimo priežastys ir pasekmès, todèl skaičiuojant jų pasitenkinimą vertinamos tiek jo priežastys, tiek pasekmės bei ryšiai tarp jų. Taigi vartotojų pasitenkinimas apskaičiuojamas taikant struktūrinių lygčių modelį (SEM). Vartotojų pasitenkinimą skaičiuojant taikant ECSI modeli, rekomenduojama naudoti PLS techniką (Eklof ir kt., 2008). Tai pagristas metodas, kuri galima taikyti skaičiuojant sudètingus priežasčių ir pasekmių santykių modelius (Gudergan ir kt., 2008). 
Tyrime naudojama programine iranga, skaičiuojanti PLS technika, vadinama SmartPLS. PLS technika skaičiuojant naudoja algoritma, kuris yra vektorių reikšmių regresijos seka. Algoritmas nusako, kokius veiksmus ir kokia tvarka turi atlikti kompiuteris, kad iš turimų pradinių duomenų gautų reikiamus teisingus rezultatus (Blonskis ir kt., 2005).

2 lentelëje pateikta ECSI modelio kintamuju itakos matrica, iš kurios matoma, kokie kintamieji lemia atitinkamą kintamaji bei kokių kintamujų koks kintamasis yra lemiamas. Pavyzdžiui, lojalumas neturi įtakos nè vienam modelio kintamajam, įvaizdžiui nedaro įtakos nè vienas modelio kintamasis (todèl pastarasis yra egzogeninis kintamasis).

Lentele 2. ECSI modelio kintamuju itakos matrica

\begin{tabular}{|l|l|l|l|l|l|l|l|}
\hline $\begin{array}{r}\text { Lemiantis } \\
\text { Lemiamas } \\
\text { kintamasis }\end{array}$ & Ivaizdis & Lūkesčiai & $\begin{array}{c}\text { Suvokiama } \\
\text { kokybė }\end{array}$ & $\begin{array}{c}\text { Suvokiama } \\
\text { vertė }\end{array}$ & $\begin{array}{c}\text { Pasiten- } \\
\text { kinimas }\end{array}$ & Skundai & Lojalumas \\
\hline Ivaizdis & 0 & 0 & 0 & 0 & 0 & 0 & 0 \\
\hline Lūkesčiai & 1 & 0 & 0 & 0 & 0 & 0 & 0 \\
\hline Suvokiama kokybe் & 0 & 1 & 0 & 0 & 0 & 0 & 0 \\
\hline Suvokiama vertė & 0 & 1 & 1 & 0 & 0 & 0 & 0 \\
\hline Pasitenkinimas & 1 & 1 & 1 & 1 & 0 & 0 & 0 \\
\hline Skundai & 0 & 0 & 0 & 0 & 1 & 0 & 0 \\
\hline Lojalumas & 1 & 0 & 0 & 0 & 1 & 1 & 0 \\
\hline
\end{tabular}

Šaltinis: Tenenhaus ir kt., 2005

\section{Tyrimo rezultatų analizè}

Atliekant anketinę apklausą respondentai turejjo pagal 10 balų skalę i̇vertinti pateiktus teiginius, kurie skirti Kauno picerijų darbui įvertinti.

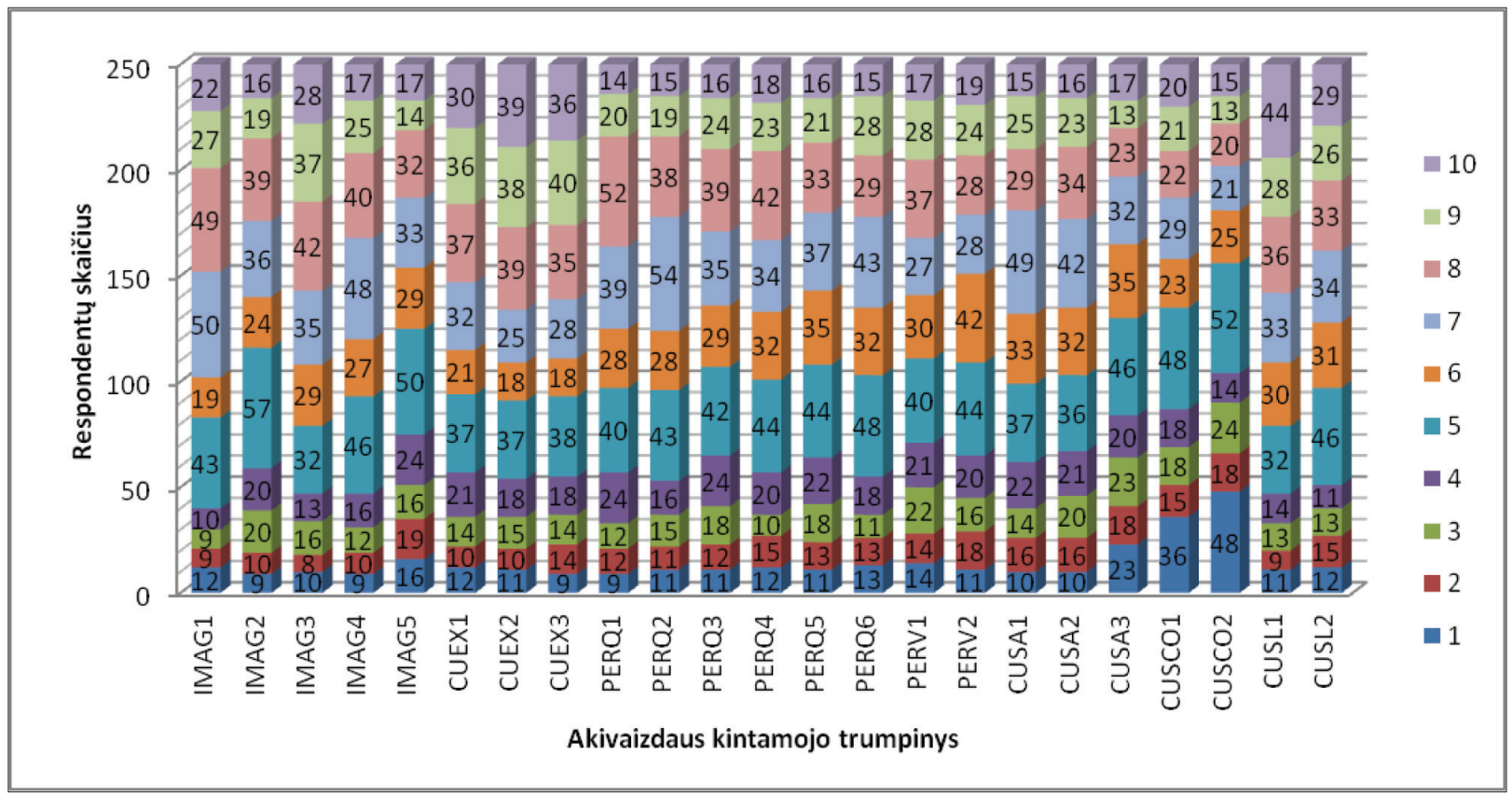

1 pav. Teiginių dèl Kauno picerijų ivvertinimo dažnumas 
1 paveiksle pateiktas respondentų teiginiu įvertinimo dažnumas, vertinant teiginius apie Kauno picerijas. Kaip matome, reikšmès „,0“, reiškiančios, kad respondentas dèl atitinkamo teiginio neturi nuomonès, nepažymejjo nè vienas respondentas. Galima teigti, kad respondentai turi susiformavę nuomones apie Kauno picerijas. Tyrimo rezultatai rodo, kad daugiausiai reikšmių „1“ pažymèta vertinant teiginius, kurie susiję su vartotoju skundais: vartotojai nelinkę skųstis, kai jų netenkina picerijos produktų ar aptarnavimo kokybè. Reikšmę „10“ daugiausiai kartų respondentai žymèjo ties teiginiu ,planuoju lankytis Kauno miesto picerijose ateityje“. Taip pat reikšmę „10“ nemažai respondentų (15-16 \%) rinkosi, vertindami lūkesčius matuojančius akivaizdžius kintamuosius, todèl galima teigti, kad vartotojų lūkesčiai dèl Kauno picerijų buvo dideli. Ivvertinimus „," ir „9“ respondentai buvo linkę gana dažnai (18-32 \%) žymèti vertindami Kauno miesto picerijų ivvaizdi bei lūkesčius atskleidžiančius akivaizdžius kintamuosius, tačiau toliau vertinant suvokiamą kokybę, suvokiamą vertę ir pasitenkinimą atskleidžiančius akivaizdžius kintamuosius šių reikšmių žymėjimo dažnis gerokai sumažėjo (13-28 \%). 1 paveiksle ryškiai išsiskiria reikšmès , ,5“ ir ,7“: vertinant visus kintamuosius jos žymètos daugiausiai kartu, todèl galima teigti, kad respondentų nuomonè apie Kauno miesto picerijas yra vidutiniška.

Apibendrinant apklausos rezultatus, 2 paveiksle pateikti neatskleistų kintamujų indeksai. Kaip matome, ECSI indeksas lygus 58. Galima teigti, kad vartotojų pasitenkinimas Kauno picerijomis yra mažas, nors ne daug trūksta iki vidutinio pasitenkinimo lygio, kuris pasiekiamas, kai ECSI yra lygus arba didesnis nei 60 (Pan European Customer Satisfaction Report, 2011).

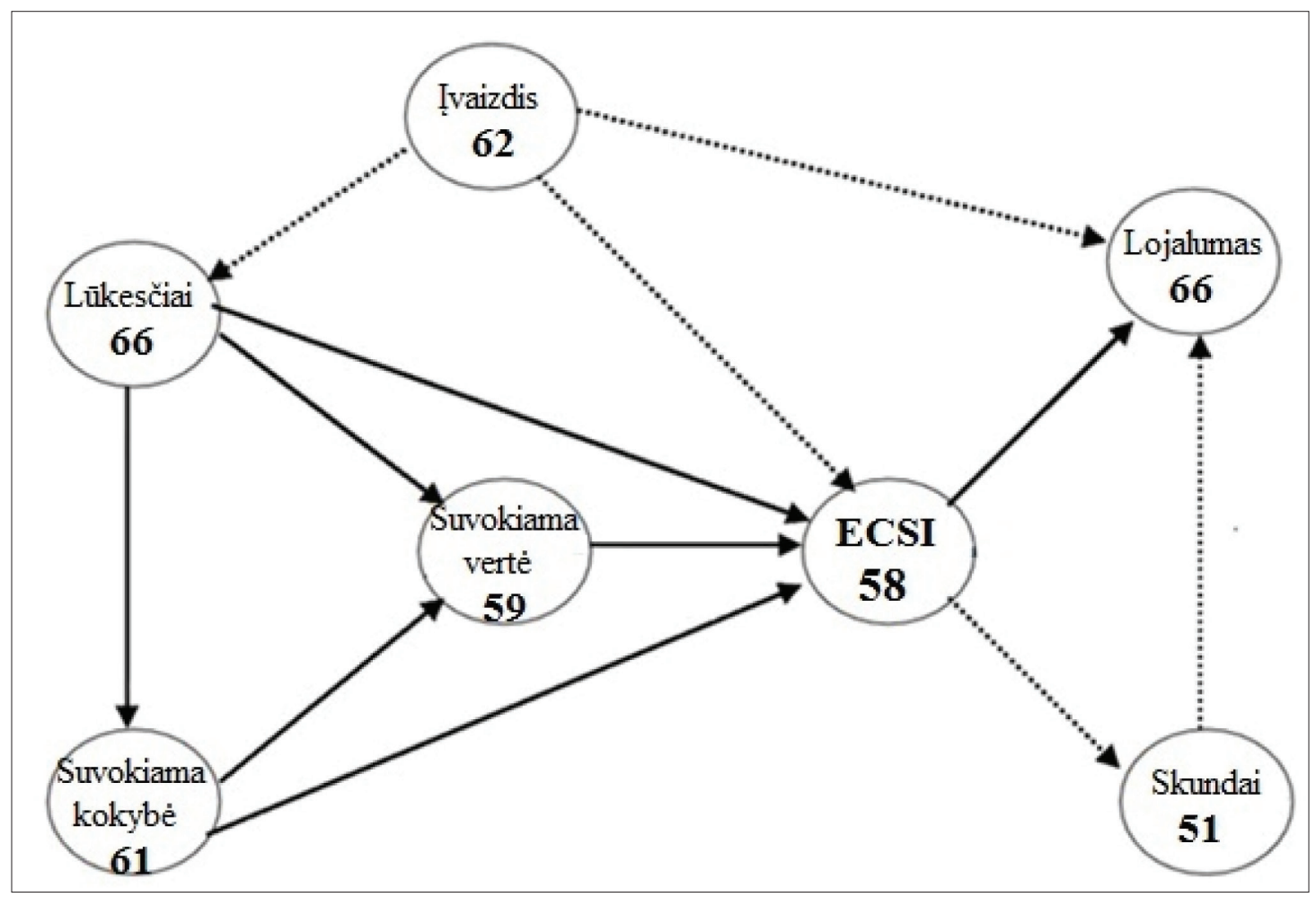

2 pav. Neatskleistų kintamujų indeksai

Vienas didžiausių indeksų pateiktame modelyje - vartotojų lūkesčių Galima teigti, kad Kauno miesto picerijos skatina gana aukštus vartotojų lūkesčius, tačiau jų nepatenkina, todėl vartotojų pasitenkinimas yra mažesnis nei jų lūkesčiai. Picerijoms nereikètų formuoti vartotojams tokių aukštų lūkesčių, tada galètu juos pranokti, taip sukeldamos jų susižavẻjimą. Tokị patị indeksą turi vartotojų lojalumo kintamasis. Taigi vartotojų lojalumas Kauno miesto picerijoms yra vidutinio lygio.

Vartotojų skundų indeksas yra mažiausias modelyje, todèl dar kartą galima teigti, kad Kauno miesto vartotojai nėra linkę skųstis picerijų produktų ar aptarnavimo kokybe. Susiformavęs Kauno miesto picerijų 
įvaizdis taip pat yra vidutiniškas, indikuojantis įvaizdžio gerinimo būtinybę. Tiek suvokiamos kokybės, tiek suvokiamos vertės indeksai svyruoja ties riba tarp mažo ir vidutinio lygio - tiek kokybę, tiek vertę vartotojai vertina vidutiniškai. 2010 metais bendras absoliutus Lietuvos vartotojų pasitenkinimo indeksas buvo 71 (Pan European Customer Satisfaction Report, 2011), tačiau nė vienas nagrinėjamo modelio indeksas šios reikšmès nepasiekè. Tyrimo duomenys rodo, kad Kauno picerijos nėra užtikrintos, kad jų verslo ateityje laukia sėkmè. Nei vienas kintamasis nepasieke indekso reikšmės 75 , kuri reiškia aukštą atitinkamo kintamojo lygi ir prognozuoja verslo sẻkmę ateityje.

3 paveiksle pateikti neatskleistų kintamujų determinacijos ir kelio koeficientai tarp neatskleistų kintamųjų bei tarp neatskleistų ir akivaizdžių kintamujų.

Determinacijos koeficientas $\left(R^{2}\right)$ rodo, kokią dali atitinkamo kintamojo dispersijos paaiškina kiti modelio kintamieji, jis gali būti matuojamas procentais (Turkyilmaz, Ozkan, 2007). İvaizdžio kintamasis yra

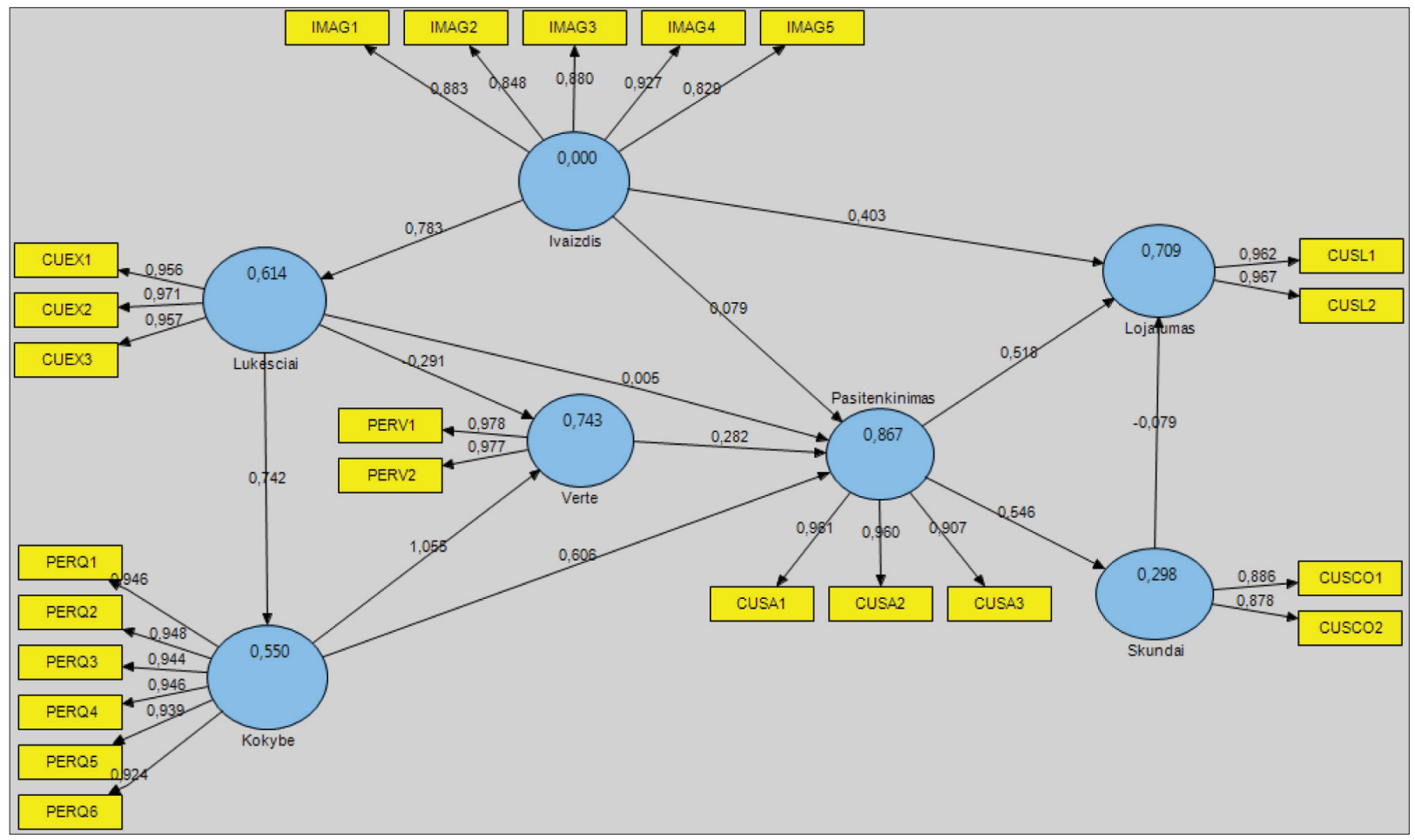

3 pav. Kintamujų kelio ir determinacijos koeficientai

egzogeninis, todèl jam determinacijos koeficientas neskaičiuojamas. Didžiausias $R^{2}$ yra kintamojo „pasitenkinimas" - 86,7 proc. Galima teigti, kad modelis tiksliai aprašo pasitenkinimo lygti. Kintant pasitenkinimo rodikliui, 86,7 proc. šio kitimo paaiškina įvaizdžio, lūkesčių, kokybès ir vertės kintamujų kitimas. Regresijos tiesè taip pat gerai aprašo vertès ir lojalumo kintamuosius, paaiškindama atitinkamai 74,3 proc. ir 70,9 proc. vertės ir lojalumo kintamujų dispersijas. Lūkesčiu ir kokybès $R^{2}$ atitinkamai lygūs 61,4 proc. ir 55 proc., taigi šių kintamujų regresijos lygtys juos pakankamai aprašo. Kintamojo „skundai“ $R^{2}$ yra 29,8 proc., kas nèra pakankama, kad būtų galima teigti, jog modelis tinkamai aprašo kintamojo duomenis.

Nors beveik visų kintamujų determinacijos koeficientai yra pakankamai aukšti ir galima teigti, kad modelis gerai aprašo kintamujų lygtis, tačiau tai nereiškia, kad visi kintamieji modelyje yra būtini.

Kelio koeficientai rodo tiesioginę vieno kintamojo ịtaką kitam kintamajam, tačiau atitinkamą kintamaji veikia ne tik tiesioginiai veiksniai, pavyzdžiui: visa kokybès itaka pasitenkinimui lygi tiesioginès kokybès ¿̇takos pasitenkinimui ir netiesioginès kokybès ¿̇takos pasitenkinimui sumai (kokybès itaka vertei $\rightarrow$ vertès ịtaka pasitenkinimui). Tokią vieno kintamojo ịtaką kitam kintamajam vadinsime bendra įtaka (žr. 3 lentelę). 
Lentele 3. Neatskleistų kintamujų kelio koeficientai, bendra ịtaka ir $T$ kriterijų reikšmès

\begin{tabular}{|c|c|c|c|c|}
\hline Kintamieji & $\begin{array}{c}\text { Kelio } \\
\text { koeficientas }\end{array}$ & $\begin{array}{c}T \text { kriterijus } \\
\text { (kelio koeficiento) }\end{array}$ & Bendra ịtaka & $\begin{array}{c}T \text { kriterijus } \\
\text { (bendros itakos) }\end{array}$ \\
\hline Ivaizdis $\rightarrow_{\text {Lojalumas }}$ & 0,403 & 4,998 & 0,661 & 12,803 \\
\hline Ivaizdis $\rightarrow_{\text {Lūkesčiai }}$ & 0,783 & 26,840 & 0,783 & 26,840 \\
\hline Ivaizdis $\rightarrow$ Pasitenkinimas & 0,079 & 1,243 & 0,544 & 9,603 \\
\hline Kokybė $\rightarrow$ Pasitenkinimas & 0,606 & 7,554 & 0,904 & 14,858 \\
\hline Kokybe் $\rightarrow$ Vertė & 1,055 & 25,763 & 1,055 & 25,763 \\
\hline Lūkesčiai $\rightarrow_{\text {Kokybè }}$ & 0,742 & 18,526 & 0,742 & 18,526 \\
\hline Lūkesčiai $\rightarrow$ Pasitenkinimas & 0,005 & 0,174 & 0,594 & 8,011 \\
\hline Lūkesčiai $\rightarrow$ Vertè & 0,291 & 6,144 & 0,492 & 8,220 \\
\hline Pasitenkinimas $\rightarrow_{\text {Lojalumas }}$ & 0,519 & 6,181 & 0,475 & 5,791 \\
\hline Pasitenkinimas $\rightarrow$ Skundai & 0,546 & 10,148 & 0,546 & 10.148 \\
\hline Skundai $\rightarrow_{\text {Lojalumas }}$ & $-0,079$ & $-1,783$ & $-0,079$ & $-1,584$ \\
\hline Vertè $\rightarrow$ Pasitenkinimas & 0,282 & 6,538 & 0,282 & 6,538 \\
\hline
\end{tabular}

Kaip matyti 3 lentelèje, ivvaizdžio itaka lūkesčiams, remiantis kelio koeficientu, yra didelè ir sutampa su bendra ịtaka, tai reiškia, kad iš visų nagrinejjamų kintamujų vartotojų lūkesčius lemia tik organizacijos įvaizdis. $T$ kriterijaus reikšmé didesnè nei 1,96, todèl tiesioginè itaka yra reikšminga. Tiesioginè ịvaizdžio itaka lojalumui yra vidutinè, tačiau reikšminga $(T>1,96)$, ivvaizdžio kintamajam padidèjus vienetu, lojalumas padidèja 0,403 . Bendra įvaizdžio įtaka lojalumui yra didelè ir reikšminga $(T>1,96)$. Tiesiogine įvaizdžio itaka pasitenkinimui yra labai maža ir nereikšminga $(T<1,96)$, tačiau bendra ịvaizdžio įtaka pasitenkinimui yra didelè ir reikšminga $(T>1,96)$, todèl ši kintamaji modelyje reikia palikti, tačiau nereikia nurodyti, kad jis tiesiogiai lemia pasitenkinimą. Tiek tiesioginè, tiek bendra kokybès įtaka pasitenkinimui yra didelès ir reikšmingos $(T>1,96)$. Pati didžiausia ịtaka visame modelyje yra kokybės įtaka vertei, kokybės rodikliui padidejus vienetu, vertès rodiklis padideja 1,055 vieneto. Ši itaka yra tiesioginè ir reikšminga $(T>1,96)$. Lūkesčiu itaka kokybei yra didelè, tiesioginè ir reikšminga $(T>1,96)$. Pasitenkinimo lūkesčiai tiesiogiai nelemia (kelio koeficientas apskaičiuotas $0,005, T<1,96$ ), bendra itaka yra didele ir reikšminga $(T>1,96)$. Tiesioginè lūkesčiu įtaka vertei yra vidutiniška ir reikšminga, bendra ịtaka yra didesnè nei tiesioginè, tačiau taip pat vidutiniška ir reikšminga $(T>1,96)$. Vertès įtaka pasitenkinimui yra tiesioginè, vidutinè ir reikšminga $(T>1,96)$. Pasitenkinimo ịtaka tiek lojalumui, tiek skundams yra tiesioginé, didelè ir reikšminga $(T>1,96)$. Skundų itaka lojalumui yra tiesioginè atvirkštinè, tačiau labai maža ir statistiškai nereikšminga $(T<1,96)$.

Neatskleistų kintamujų koreliacijos koeficientai pateikiami 4 lentelëje.

Lentele 4. Neatskleistų kintamujų koreliacijos koeficientai

\begin{tabular}{|l|l|l|l|l|l|l|l|}
\hline \multicolumn{1}{|c|}{ Kintamieji } & \multicolumn{1}{c}{ Ivaizdis } & \multicolumn{1}{c|}{ Kokybe் } & Lojalumas & Lūkesčiai & Pasitenkinimas & Skundai & Vertè \\
\hline Ivaizdis & 1 & 0 & 0 & 0 & 0 & 0 & 0 \\
\hline Kokybe் & 0,872 & 1 & 0 & 0 & 0 & 0 & 0 \\
\hline Lojalumas & 0,796 & 0,854 & 1 & 0 & 0 & 0 & 0 \\
\hline Lūkesčiai & 0,783 & 0,742 & 0,713 & 1 & 0 & 0 & 0 \\
\hline Pasitankinimas & 0,839 & 0,917 & 0,813 & 0,656 & 1 & 0 & 0 \\
\hline Skundai & 0,529 & 0,494 & 0,417 & 0,437 & 0,546 & 1 & 0 \\
\hline Verte & 0,771 & 0,839 & 0,757 & 0,492 & 0,855 & 0,458 & 1 \\
\hline
\end{tabular}


Neatskleistų kintamujų itaka visiems akivaizdiems kintamiesiems nustatyta didelè (mažiausias kelio koeficientas yra 0,829$)$ ir reikšminga $(T>1,96)$. Išorinio svorio koeficientai ne mažesni kaip 0,7 . Tai reiškia, kad visi akivaizdūs kintamieji ir apskaičiuotos jiems daromos įtakos reikšmès yra patikimos.

4 lentelëje pateikti neatskleistų kintamujų koreliacijos koeficientai. Koreliacija nereiškia kintamujų tarpusavio itakos, o parodo jų tarpusavio ryšio stiprumą. Kaip matome, silpnos koreliacijos tarp kintamujų nėra. Maža koreliacija yra tarp skundų ir kokybès, skundų ir lojalumo, vertès ir lūkesčių, skundų ir lūkesčių bei skundų ir vertès. Tai reiškia, kad tarp skundų ir kitų neatskleistų kintamujų yra mažas ryšys, kas patvirtina, kad šio kintamojo regresijos lygtis ji aprašo nepakankamai gerai. Maža koreliacija taip pat pastebima tarp vertės ir lūkesčių. Vidutinė koreliacija matoma tarp skundų ir įvaizdžio, pasitenkinimo ir lūkesčiu, pasitenkinimo ir skundų. Vèlgi tie patys kintamieji - lūkesčiai ir skundai, taigi galima teigti, kad tarp skundų ir kitu modelio kintamujų yra maža ir vidutinè koreliacija, tarp lūkesčių ir vertės bei pasitenkinimo yra atitinkamai mažas ir vidutinis ryšys. Labai stiprus ryšys yra tarp kokybės ir pasitenkinimo. Tarp likusių kintamujų pastebimas stiprus ryšys.

Neatskleistų kintamujų koreliacijos koeficientų, pakeltų kvadratu, ir 5 lentelèje pateiktų išgaunamos vidutinès dispersijos (AVE) reikšmiu palyginimas leidžia teigti, kad duomenys pagrịsti, t. y. tie kintamieji, kurie neturi būti susiję, iš tiesų ir nèra susiję. Palyginę šiuos duomenis matome, kad visų kintamuju AVE reikšmės yra didesnès už atitinkamų kintamujų didžiausią kvadratu pakelto koreliacijos koeficiento reikšmę, nes pati mažiausia AVE rodiklio reikšmė $(0,764)$ yra didesnẻ už pačią didžiausią koreliacijos koeficiento, pakelto kvadratu, reikšmę $(0,760)$.

Lentele 5. Neatskleistų kintamujų AVE, sudètinio patikimumo, Cronbach alfa ir bendrumo rodikliai

\begin{tabular}{|c|c|c|c|c|}
\hline \begin{tabular}{|ll} 
Kintamasis & Rodiklis
\end{tabular} & AVE & Sudètinis patikimumas & Cronbach alfa & Bendrumas \\
\hline Iاvaizdis & 0,764 & 0,942 & 0,922 & 0,764 \\
\hline Kokybė & 0,886 & 0,979 & 0,974 & 0,886 \\
\hline Lojalumas & 0,930 & 0,964 & 0,925 & 0,930 \\
\hline Lūkesčiai & 0,925 & 0,974 & 0,959 & 0,925 \\
\hline Pasitenkinimas & 0,889 & 0,960 & 0,937 & 0,889 \\
\hline Skundai & 0,777 & 0,875 & 0,714 & 0,777 \\
\hline Vertè & 0,955 & 0,997 & 0,953 & 0,955 \\
\hline
\end{tabular}

Ištyrę 5 lentelëje pateiktus rodiklius matome, kad sudètinio patikimumo (kiekvieno kintamojo bendras patikimumas) ir Cronbach alfa rodiklių reikšmès visiems neatskleistiems kintamiesiems yra didesnès kaip 0,7. Galima teigti, kad visi neatskleisti kintamieji yra patikimi ir homogeniški. AVE rodiklio reikšmès taip pat yra ne mažesnès kai 0,7, nors reikalaujama, kad šios reikšmès būtų ne mažesnès kaip 0,5. Paklaidų dispersija nedidelè, kintamiesiems būdinga konvergencija ir duomenys yra pagrịsti. Bendrumo rodiklis yra kvadratu pakelta koreliacija tarp akivaizdžių kintamujų ir jais matuojamo neatskleisto kintamojo. Šis rodiklis atskleidžia atitinkamo kintamojo dispersijos procentą, kuris paaiškina akivaizdžius kintamuosius. Šiuo atveju mažiausia bendrumo rodiklio reikšmė yra 0,764, tai reiškia, kad vidutiniškai 76,4 \% atitinkamų kintamujų dispersijos paaiškina jais matuojamas neatskleistas kintamasis. Kitų kintamujjų bendrumo rodiklis yra aukštesnis. Kadangi reikalaujama, kad bendrumo rodiklis būtų ne mažesnis kaip 0,5, o šiuo atveju visi bendrumo rodiklio duomenys yra gerokai didesni, galima teigti, kad kintamieji yra patikimi.

Irodytas modelio patikimumas ir duomenų pagrisstumas leidžia teigti, kad apskaičiuoti neatskleistų kintamujų indeksai, neatskleistu kintamuju itakos kryptys bei įtakos stiprumai yra teisingi. Gauti tyrimo rezultatai lèmė Europos vartotojų pasitenkinimo indekso modelio korekciją (žr. 4 pav.), rekomenduojamą skaičiuojant vartotojų pasitenkinimą visomis picerijomis arba konkrečia Kauno miesto picerija. 


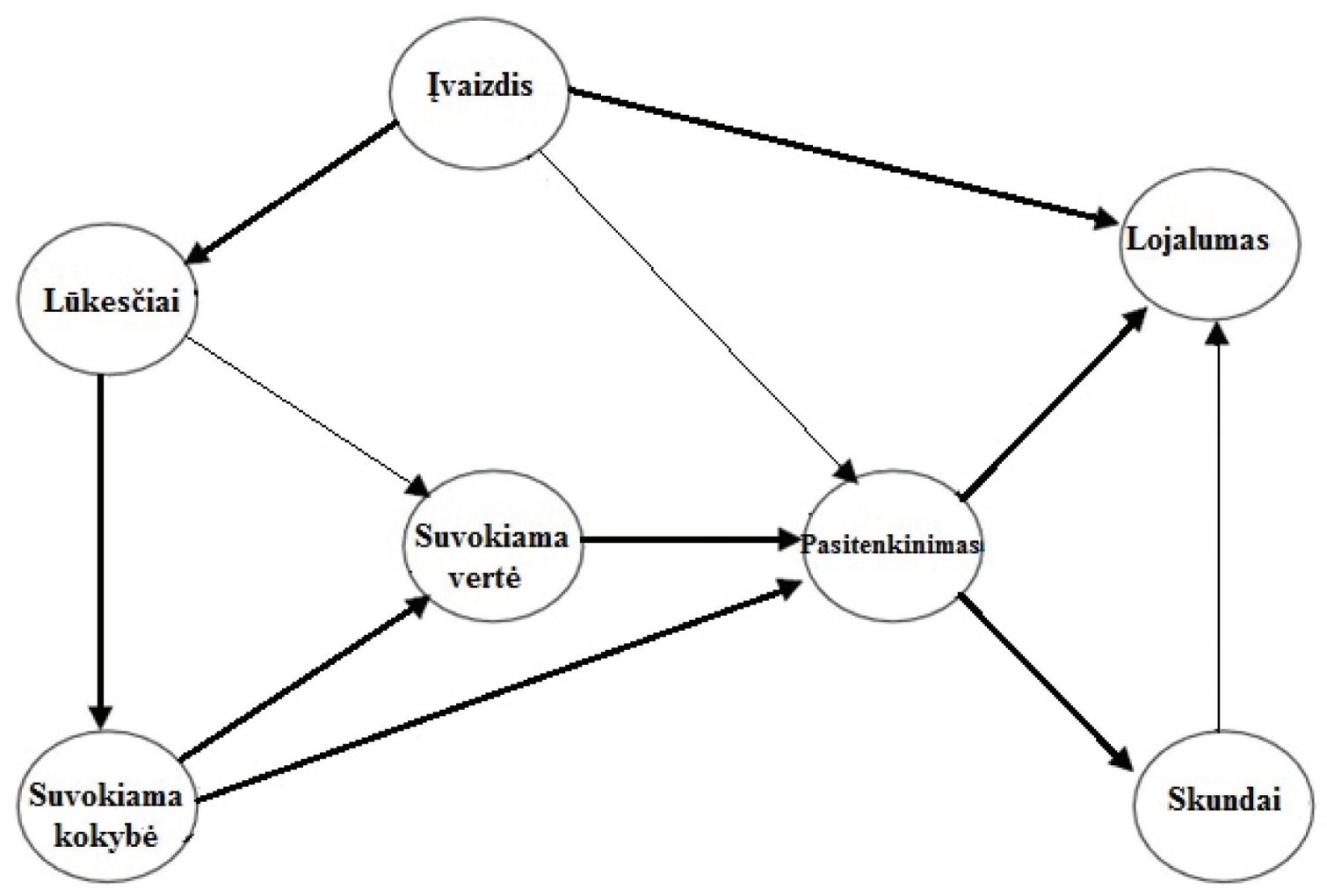

4 pav. Vartotoju pasitenkinimo Kauno miesto picerijomis modelis

Visi 7 neatskleisti kintamieji, pavaizduoti 4 paveiksle, modelyje išlieka tie patys, kaip ir pateikti vartotoju pasitenkinimo modelyje, kuris naudotas atliekant tyrima, nes bendra visų neatskleistų kintamuju itaka atitinkamiems modelio kintamiesiems yra reikšminga. Juodomis paryškintomis rodyklèmis pavaizduota tiesioginè vieno neatskleisto kintamojo įtaka kitam neatskleistam kintamajam rodyklès kryptimi. Šios įtakos yra tiesioginès ir reikšmingos, lemiančios atitinkamą vartotojų pasitenkinimo lygị ir jo padarinius organizacijai. Neparyškintomis rodyklèmis (rodyklès kryptimi) nurodytos tos tiesioginès neatskleistų kintamuju ịtakos atitinkamiems neatskleistiems kintamiesiems, kurios nei įrodytos, nei paneigtos. Tai reiškia, kad kartais šios itakos gali egzistuoti, tačiau nebūtinai visais atvejais. Vartotojų lūkesčių tiesioginè įtaka vartotojų pasitenkinimui iš šio modelio pašalinta. Šiuo atveju sutinkama su kai kurių autorių (Martensen ir kt., 2000; Johnson ir kt., 2001; O’Loughlin ir kt., 2004) nuomone, kad vartotojų lūkesčiai neturi tiesioginès įtakos vartotoju pasitenkinimui. Tyrimo rezultatų analizè rodo, kad bendra vartotojų lūkesčių itaka vartotojų pasitenkinimui yra didelè ir reikšminga, todèl jų lūkesčių neatskleistas kintamasis modelyje paliekamas.

\section{Išvados}

İvairūs autoriai mini daug skirtingų vartotojų pasitenkinimą lemiančių veiksnių, tačiau daugelio jų ịtaka vartotojų pasitenkinimui neirodyta. Be to, autoriai nesutaria dèl pagrindinių veiksnių, kurie lemia vartotojų pasitenkinima, ittakos reikšmès. Apibendrinus nagrinètų autorių nuomones, skiriami šie vartotojų pasitenkinimą lemiantys veiksniai: organizacijos įvaizdis, vartotoju lūkesčiai, vartotoju suvokiama kokybè, vartotoju suvokiama vertè. Dẻl vartotojų pasitenkinimo ilgo laikotarpio padarinių organizacijai daugelis autoriu sutaria, jie teigia, kad didesnis vartotoju pasitenkinimas organizacijos produktais ar paslaugomis yra vienas veiksnių, lemiančiu didesnę organizacijos vertę, tačiau dẻl tiesioginių vartotojų pasitenkinimo pasekmių or- 
ganizacijai kai kurie autoriai nesutaria, todèl skiriamos tokios pagrindinės pasekmės organizacijai: vartotoju lojalumas, vartotoju skundai.

Tyrimo rezultatų analize nustatyti vartotojų pasitenkinimo modelio kintamujų indeksai ir jų apibendrinimas leidžia teigti, kad vartotojų pasitenkinimas Kauno miesto picerijų teikiamomis paslaugomis yra mažas. Tyrimo duomenys leidžia daryti išvadą, kad siekiant didesnio vartotoju pasitenkinimo picerijomis, svarbiausia suderinti vartotoju lükesčius ir produktu bei aptarnavimo kokybę.

Rengiant vartotoju pasitenkinimo Kauno miesto picerijomis modeli nustatyta, kad vartotoju lūkesčiai vartotoju pasitenkinimui Kauno miesto picerijomis tiesiogines įtakos neturi. Nepatvirtinta, bet ir nepaneigta lūkesčiu tiesioginè įtaka suvokiamai vertei, ivaizdžio - pasitenkinimui, vartotojų skundų - lojalumui, todèl šios itakos modelyje pavaizduotos. Analizuojant kintamujų itakas (dèl picerijų) nustatyta, kad visi modelio kintamieji yra reikšmingi, apskaičiuojant vartotoju pasitenkinima bei jo pasekmes organizacijai.

Remiantis atlikto tyrimo rezultatais, Kauno miesto picerijoms rekomenduojama didinti ne savo vartotojų lūkesčius, bet teikiamų produktų ir paslaugų kokybę arba užtikrinti tokị kokybės ir kainos lygi, kad vartotojų pasitenkinimas pasiektų vidutini lygi.

\section{Literatūra}

Appiah-Gyimah, R., Boohene, R. A., Agyapong, G. K. Q., Boohene, K. A. (2011). Customer Satisfaction in the Outdoor Advertising Industry: A Case of Alliance Media Ghana Limited. International Joumal of Marketing Studies, Vol. 3, No. 2, May.

Bayol, M. P., Foye, A., Tellier, C., Tenenhaus, M. (2000). Use of PLS Path Modelling to estimate the European Consumer Satisfaction Index (ECSI) modeli. Statistica Applicata, Vol. 12, No. 3.

Blonskis, J., Bukšnaitis, V., Jusas, V. ir kt. (2005). C++ Builder. Kaunas: Smaltijos leidykla.

Boulding, W., Kalra, A., Staelin, R., Zeithaml, V. A. (1993). A Dynamic Process Model of Service Quality: From Expectations to Behavioral Intentions. Journal of Marketing Research, Vol. 30, February.

Cardozo, R. N. (1965). An Experimental Study of Customer Effort, Expectation, and Satisfaction. Journal of Marketing Research, Vol. 2, August.

Chan, L. K., Hui, Y. V., Lo, H. P., Tse, S. K., Tso, G. K. F., Wu, M. L. (2003). Consumer satisfaction index: new practice and findings. European Journal of Marketing, Vol. 37, No. 5/6.

Ciavolino, E., Dahlgaard, J. J. (2007). ECSI - Customer Satisfaction Modelling and Analysis: A Case Study. Total Quality Management, Vol. 18, No. 5.

Day, R. L. (1984). Modeling choices among alternative responses to dissatisfaction. Advances in Consumer Research, Vol. 11, January.

Eklof, J., Selivanova, I. (2008). Human aspect in service quality: EPSI benchmark studies. Total Quality Management, Vol. 19, No. 7/8.

Fornell, C., Johnson, M. D., Anderson, E. W., Cha, J., Bryant, B. E. (1996). The American Customer Satisfaction Index: Nature, Purpose, and Findings. Journal of Marketing, Vol. 60, October.

Fornell, C. (1992). A National Customer Satisfaction Barometer: The Swedish Experience. Journal of Marketing, Vol. 56, January.

Gudergan, S. P., Ringle, C. M., Wende, S., Will, A. (2008). Confirmatory tetrad analysis in PLS path modeline. Journal of Business Research, Vol. 61.

Yang, X., Tian, P., Zhang, Z. (2005). A Comparative Study on Several National Customer Satisfaction Indices (CSI). Aetna School of Management, Shanghai Jiao Tong University, Shanghai, P. R. China.

Johnson, M. D., Anderson, E. W., Fornell, C. (1995). Rational and Adaptive Performance Expectations in a Customer Satisfaction Framework. Journal of Consumer Research, Vol. 21, March.

Johnson, M. D., Gustafsson, A., Andreassen, T. W., Lervik, L., Cha, J. (2001). The evolution and future of national customer satisfaction index models. Journal of Economic Psychology, Vol. 22.

Krishan, A. R., Hari, K. (2011). Factors Determining Customer Satisfaction in Consumer Durable White Goods: Factor Analysis Approach. Asia Pacific Journal of Research in Business Management, Vol. 2, June.

Kristensen, K., Martensen, A., Gronholdt, L. (1999). Measuring the impact of buying behaviour on customer satisfaction. Total Quality Management, Vol. 10, No. 4/5.

Lietuvos statistikos departamentas. (2012). Prieiga internetu: http://www.stat.gov.lt/lt/ [žiūrèta 201202 23].

Martensen, A., Gronholdt, L., Kristensen, K. (2000). The drivers of customer satisfaction and loyalty: cross-industry findings from Denmark. Total Quality Management, Vol. 11, No. 4. 
O’Loughlin, C., Coenders, G. (2004). Estimation of the European Customer Satisfaction Index: Maximum Likelihood versus Partial Least Squares. Application to Postal Services. Total Quality Management and Business Excellence, Vol. 15, No. 9.

Pan European Customer Satisfaction Report. (2011). Prieiga internetu: http://www.epsi-rating.com/en/News/the-paneuropean-customer-satisfaction-report-1999-2009-is-now-available.html [žiūrèta 201202 20].

Tenenhaus, M., Vinzi, V. E., Chatelin, Y. M., Lauro, C. (2005). PLS path modeline. Computational Statistics and Data Analysis, Vol. 48.

Turkyilmaz, A., Ozkan, C. (2007). Development of a customer satisfaction index model, An application to the Turkish mobile phone sector. Industrial Management and Data Systems, Vol. 107, No. 5.

\title{
DETERMINATION OF CUSTOMER SATISFACTION WITH PIZZERIAS IN KAUNAS
}

\author{
Viktorija Grigaliūnaité, Lina Pilelienè \\ Vytautas Magnus University (Lithuania)
}

\section{Summary}

Relevance of the research. Food can be called as a necessary good for human existence and welfare. Nowadays, as a speed of our life is intensifying and busyness is growing, many fast-food restaurants are establishing and getting their part in the catering service field. Due to a technical progress (people can reach foreign countries in a few hours) and globalization, businesses are not framed by a borders of a particular country any longer - they are expanding to other countries and cultures. Contemporary society is facing the possibility to try and make preferences to cuisines by many different countries. Consequently, many restaurants serving other countries' traditional meals can be found in Lithuania.

The popularity of foreign cuisine restaurants is growing in Kaunas, as well as in all the country. According to Lithuanian Department of Statistics (2012), there were more that 330'000 inhabitants in Kaunas in 2011; moreover, there were 470 registered enterprises providing catering activities and sharing 26200 seats. The figures highlight that amount of seats in catering industry in Kaunas is only 13 times smaller than the number of inhabitants. Accordingly, it can be stated that catering is a very popular service in society. Considering that one of the most popular foreign cuisines in Lithuania is Italian cuisine, pizzerias were chosen under consideration. Accordingly, scientific problem solved in this article is: what is customer satisfaction with pizzerias' services in Kaunas and what are the factors determining their satisfaction.

The object of the article is customer satisfaction with pizzerias in Kaunas.

The aim of the article is to evaluate customer satisfaction with pizzerias in Kaunas.

To meet the aim of the article following tasks were set:

- To reveal the conception and models of customer satisfaction.

- To perform the research on customer satisfaction with pizzerias in Kaunas.

- To design the model of customer satisfaction with pizzerias in Kaunas.

Research methods. On purpose of analysing conception and models satisfaction which could be used for the research, the theoretical analysis and synthesis was provided. Customers' attitudes and evaluations towards pizzerias in Kaunas were determined providing the questionnaire research. Structural equation modelling (SEM) using partial least squares (PLS) path modelling methodology was applied for statistical analysis.

After the analysis of scientific literature it can be concluded that various authors highlight different customer satisfaction determinants; however many of these determinants lack scientific substantiation. Moreover, there is a polemic about the impact existence of main determinants. As main determinants of customer satisfaction can be named: organization's image, customer expectations, customer perceived quality, customer perceived value. Analyzing long-term impact of customer satisfaction, many authors state that bigger custo- 
mer satisfaction is one of the factors providing organization's value; however, some outcomes of satisfaction are being criticized and held as indirect, those are: customer loyalty, customer complaints.

The indexes of customer satisfaction variables and their interpretation made during the research, leads to a conclusion that customer satisfaction with pizzerias in Kaunas is low. Research results let us state that endeavoring to reach greater customer satisfaction with pizzeria most important is balance between customer expectations and product or service quality.

While designing the model of customer satisfaction with pizzerias in Kaunas it was determined that customer expectations have no direct impact on customer satisfaction with pizzerias in Kaunas. The direct impact of customer expectation on perceived value, image's impact on satisfaction, and customer's complaints' impact on loyalty were neither substantiated, nor unsubstantiated. Therefore, latter impacts were showed at the designed model. During the analysis of variables' impacts on satisfaction (with pizzerias) it was determined that all the variables included into a model are significant for calculation of customer satisfaction and its' outcomes for the organization.

Considering research results for pizzerias in Kaunas it can be recommended to stop elevating customer expectations, herewith improving product and service quality, or to maintain balance level of quality and price which would lead customer satisfaction to at least an average level.

KEY WORDS: Catering services, Customer satisfaction, ECSI, Kaunas.

JEL CODES: L660, M310. 